\title{
PENEGAKAN HUKUM NASIONAL SEBAGAI UPAYA MENANGGULANGI TINDAK PIDANA MENGGELANDANG DAN MENGEMIS DI KABUPATEN BULELENG
}

\author{
Galih Riana Putra Intaran ${ }^{1}$, Ni Putu Rai Yuliartini ${ }^{1}$, Dewa Gede Sudika Mangku² \\ Jurusan IImu Hukum \\ Universitas Pendidikan Ganesha \\ Singaraja

\begin{abstract}
e-mail :\{galihriana@gmail.com ${ }^{1}$, raiyuliartini@gmail.com¹, dewamangku.undiksha@gmail.com²
\end{abstract}

\begin{abstract}
Abstrak
Penelitian ini bertujuan untuk mengetahui apa saja faktor penghambat dan pendukung penegakan hukum nasional terhadap Gepeng serta upaya yang dilakukan untuk menanggulangi Gepeng di Kabupaten Buleleng. Penelitian ini merupakan penelitian hukum empiris, yang bersifat deskriptif. Penelitian ini dilakukan di Kabupaten Buleleng dengan menggunakan teknik pengumpulan data berupa observasi, wawancara, dan studi dokumen. Penelitian ini menggunakan sumber data yang berasal dari penelitian langsung dilapangan yang didukung dengan bahan hukum yang terdiri dari, peraturan perundang-undangan, jurnal, artikel, literatur-literatur serta karya tulis yang relevan dengan pokok permasalahan yang dikaji. Hasil penelitian menunjukan bahwa faktor penghambat penegakan hukum nasional adalah faktor substansi hukum dimana Gepeng belum disebutkan dalam Perda No.6 tahun 2009 dan belum ada aturan pidana bagi masyarakat pemberi Gepeng, faktor struktur hukum yaitu terkait dengan kinerja dari aparat penegak hukum yang kurang maksimal, faktor budaya hukum yaitu kurang pedulinya masyarakat Buleleng terkait permasalahan Gepeng dan masih adanya masyarakat pemberi kepada Gepeng. Sedangkan faktor pendukung adalah faktor struktur hukum yang berupa sarana/fasilitas yang menunjang dari aparat penegak hukum, dan faktor substansi hukum yaitu peraturan yang berlaku baik KUHP maupun Perda tetap diperlukan sebagai dasar pelaksanaan penegakan hukum. Upaya yang dilakukan guna menanggulangi tindak pidana menggelandang dan mengemis di Kabupaten Buleleng meliputi upaya penal yaitu berupa kegiatan operasi/razia guna menertibkan tempat kegiatan Gepeng, dan upaya penampungan sementara untuk sleksi guna menentukan jenis pembinaan yang akan dilakukan, selanjutnya adalah upaya non-penal yaitu program rumah tinggal kreatif yang bertujuan untuk tempat rehabilitasi mental dan pembinaan keterampilan dengan harapan dapat merubah pola pikir dan jalan hidup para Gepeng untuk mendapatkan pekerjaan yang jauh lebih baik lagi.
\end{abstract}

Kata Kunci : Gelandangan dan Pengemis, Faktor Penegakan Hukum, Upaya Penanggulangan 


\begin{abstract}
This study aims to determine what are the factors inhibiting and supporting the enforcement of national law against Gepeng as well as efforts made to tackle Gepeng in Buleleng regency. This research is an empirical legal research, which is descriptive. This research was conducted in Buleleng Regency by using data collecting technique such as observation, interview, and document study. This study uses data sources derived from direct field research supported by legal materials consisting of laws, regulations, journals, articles, literature and papers relevant to the subject matter studied. The result of the research shows that the inhibiting factor of national law enforcement is the legal substance factor where Gepeng has not been mentioned in Perda No.6 of 2009 and there is no criminal rule for Gepeng, factors of legal structure that is related to the performance of law enforcement officers who are less than the maximum, legal culture factor that is less care of Buleleng society related to Gepeng problem and still existence of giving society to Gepeng.While the supporting factor is a factor of legal structure in the form of facilities / facilities that support from law enforcement officers, and the legal substance factor that is the regulation applied both Penal Code and Perda still needed as base of law enforcement implementation. Efforts made to tackle criminal acts vandalizing and begging in Buleleng include penal efforts in the form of operations / raids to discipline the location of activities Gepeng, and temporary shelter for slots to determine the type of coaching to be performed, next is a non-penal effort that is a creative home program that aims to place mental rehabilitation and skill coaching in the hope of changing the mind and lifestyle of the Gepeng to get a much better job again.
\end{abstract}

Keywords : Bum and Beggars, Law Enforcement Factors, Countermeasures.

\section{PENDAHULUAN}

Indonesia adalah negara yang berdasarkan atas hukum (rechtsstaat), tidak berdasarkan atas kekuasaan (machtsstaat) hal tersebut tercantum dalam penjelasan atas pasal 1 ayat 3 Undang-Undang Dasar Negara Republik Indonesia Tahun 1945. Negara hukum pada dasarnya menempatkan hukum pada posisi tertinggi dalam suatu negara dimana kekuasaan haruslah tunduk pada hukum, bukan hukum yang tunduk pada kekuasaan. Hukum harus menjadi tujuan untuk melindungi kepentingan warga negaranya, karena di dalam hukum terdapat asas equality before the law (persamaan dimata hukum) yang menyamakan kedudukan warga negara dengan penguasa dimata hukum (Bakhari, 2014:72). Yang membedakan ialah fungsinya itu sendiri, yaitu pemerintah berfungsi untuk mengatur dan warga negara yang diatur.

Hukum itu dapat dilihat sebagai perlengkapan warga negara untuk menciptakan ketertiban, keamanan, kesejahteraan serta keadilan dalam kehidupan warga negara (Masriani,
2008:1). Negara Indonesia sebagai negara hukum memberlakukan hukum nasional terhadap warga negarannya. Dalam hukum nasional Indonesia menerapkan hukum privat dan hukum publik. Hukum publik yang dimaksud yaitu hukum pidana. Hukum pidana adalah hukum yang mengatur tentang kejahatan dan pelanggaran terhadap kepentingan umum (Najih, 2014:160). Bentuk pelanggaran hukum khususnya hukum pidana dalam bidang ketertiban umum adalah mengenai permasalahan gelandangan dan pengemis atau yang sering dikenal dengan sebutan "Gepeng". Keberadaan Gepeng dalam lingkungan masyarakat jelas sangat meresahkan. Karena disamping sebagai pelanggaran hukum, Gepeng juga merupakan salah satu penyakit sosial yang ditakutkan akan menimbulkan tindak pidana baru lagi di masyarakat. Karena dalam kenyataannya kehadiran Gepeng dalam masyarakat tidak dapat dibendung, bahkan tiap tahun jumlahnya cenderung semakin banyak dan sulit untuk ditanggulangi secara tuntas. 
Faktor utama yang menyebabkan banyaknya yang menjadi Gepeng adalah faktor tingginya tingkat kemiskinan, rendahnya tingkat pendidikan, kurangnya keterampilan kerja, dan faktor sosial budaya (Yusrizal, 2012:26). Gepeng jelas merupakan salah satu dampak negatif pembangunan, khususnya pada Kabupaten Buleleng. Tentunya dengan fenomena hadirnya Gepeng yang cukup tinggi di Kabupaten Buleleng menjadikan masalah serius yang harus dihadapi dari tahun ke tahun. Kondisi seperti ini sangat jelas memprihatinkan dan meresahkan masyarakat Kabupaten Buleleng. Disamping itu, masalah Gepeng tentu dapat menimbulkan citra buruk atau kesan negatif bagi Kabupaten Buleleng sebagai Kabupaten dengan ikon Kota Pendidikan, dan salah satu daerah tujuan wisata di bali yang mana seharusnya bisa mensejahterakan masyarakatnya dengan pendidikan sejak dini.

Tabel. 1

\section{Jumlah Gepeng yang terjaring razia Tim Yustisi Kabupaten Buleleng}

\begin{tabular}{|c|c|c|c|c|c|c|c|c|c|c|c|c|c|}
\hline \multirow{3}{*}{$\begin{array}{l}N \\
0\end{array}$} & \multirow{3}{*}{$\begin{array}{l}\text { Daer } \\
\text { ah } \\
\text { Asal }\end{array}$} & \multicolumn{10}{|c|}{ Tahun } & \multirow{2}{*}{\multicolumn{2}{|c|}{$\begin{array}{l}\text { Jum } \\
\text { lah }\end{array}$}} \\
\hline & & \multicolumn{2}{|c|}{$\begin{array}{l}201 \\
3\end{array}$} & \multicolumn{2}{|c|}{$\begin{array}{l}201 \\
4\end{array}$} & \multicolumn{2}{|c|}{$\begin{array}{l}201 \\
5\end{array}$} & \multicolumn{2}{|c|}{$\begin{array}{l}201 \\
6\end{array}$} & \multicolumn{2}{|c|}{$\begin{array}{l}201 \\
7\end{array}$} & & \\
\hline & & $\mathrm{L}$ & $P$ & L & $P$ & $\mathrm{~L}$ & $P$ & $\mathrm{~L}$ & $P$ & $\mathrm{~L}$ & $P$ & $\mathrm{~L}$ & $P$ \\
\hline 1 & $\begin{array}{l}\text { Peda } \\
\text { han }\end{array}$ & 6 & 4 & 6 & $\begin{array}{l}1 \\
2\end{array}$ & 4 & 6 & 8 & $\begin{array}{l}1 \\
8\end{array}$ & 1 & 3 & 2 & $\begin{array}{l}4 \\
3\end{array}$ \\
\hline 2 & Munti & $\begin{array}{l}1 \\
0\end{array}$ & 8 & $\begin{array}{l}1 \\
0\end{array}$ & $\begin{array}{l}1 \\
4\end{array}$ & 6 & 8 & $\begin{array}{l}1 \\
1\end{array}$ & $\begin{array}{l}1 \\
6\end{array}$ & 4 & 1 & $\begin{array}{l}4 \\
1\end{array}$ & $\begin{array}{l}4 \\
7\end{array}$ \\
\hline 3 & $\begin{array}{l}\text { Kamp } \\
\text { ung } \\
\text { Baru }\end{array}$ & & & & & 2 & 1 & & & & & 2 & 1 \\
\hline 4 & $\begin{array}{l}\text { Banja } \\
\text { r } \\
\text { Jawa }\end{array}$ & & & & & 1 & 1 & & & & & 1 & 1 \\
\hline 5 & $\begin{array}{l}\text { Situb } \\
\text { ondo }\end{array}$ & & & & & & & & & 6 & 3 & 6 & 3 \\
\hline
\end{tabular}

Sumber data : Dinas Sosial Kabupaten Buleleng.

Masalah Gepeng tersebut merupakan masalah yang bersinggungan dengan aspek hukum. Selama ini Pemerintah Kabupaten Buleleng bersama dengan aparat penegak hukum terkait permasalahan Gepeng, memang telah melakukan upaya-upaya penanggulangan.
Penegakkan hukum terkait dengan pelanggaran yang dilakukan oleh Gepeng memiliki beberapa landasan hukum yang dapat dijadikan acuan untuk menegakkan hukum sebagai upaya menanggulangi atau menangani masalah Gepeng. Kegiatan menggelandang dan mengemis tersebut ternyata dikualifikasikan sebagai suatu tindak pidana yaitu sebagai overtredingen (pelanggaran) di bidang ketertiban umum, sebagaimana yang diatur dalam ketentuan Pasal 504 dan 505 KUHP. Khususnya untuk Kabupaten Buleleng mengenai larangan kegiatan menggelandang dan mengemis termasuk ketentuan pidananya diatur dalam Pasal 4 ayat 2 Jo pasal 21 Perda No. 6 Tahun 2009). Sanksi pidana secara umum untuk kegiatan menggelandangan dan mengemis diatur dalam KUHP dan secara khusus diatur dalam Perda no. 6 tahun 2009. Adanya ketentuan hukum pidana yang sesuai dengan fungsi hukum tersebut, maka hukum pidana dapat dijadikan sebagai sarana untuk mengarahkan dan membina masyarakat (Susanto,2008:35).

Aturan yang tegas dan sifatnya represif mengenai upaya penanganan Gepeng memang tetap diperlukan mengingat ketentuan tersebut dapat menghambat laju serta mempersempit ruang gerak Gepeng itu sendiri. Namun dengan demikian tetap pula harus dilakukan upaya-upaya penanggulangan yang sifatnya preventif dan persuasif (Arief, 2010:77). Fakta di lapangan menunjukkan bahwa upaya-upaya penanggulangan yang dilakukan selama ini termasuk penegakan hukum nasionalnya dengan mengkhusus pada hukum pidananya masih belum berjalan dengan optimal dan terdapat beberapa kelemahan. Maka kondisi seperti ini yang membuat masalah penanggulangan Gepeng sebagai permasalahan serius, yang harus segera dicarikan jalan pemecahannya.

Maka berdasarkan uraian diatas, peneliti sangat tertarik untuk mengkaji lebih lanjut hal-hal yang berkaitan dengan faktorfaktor yang menghambat dan mendukung penegakan hukum nasional terhadap tindak pidana menggelandang dan mengemis serta upaya- upaya yang dilakukan untuk menanggulangi Gepeng di Kabupaten 
Buleleng guna meningkatkan peran dari aparat penegak hukum serta mengembalikan fungsionalisasi hukum sebagaimana yang sesuai dengan ketentuan negara hukum dan juga mengoptimalkan

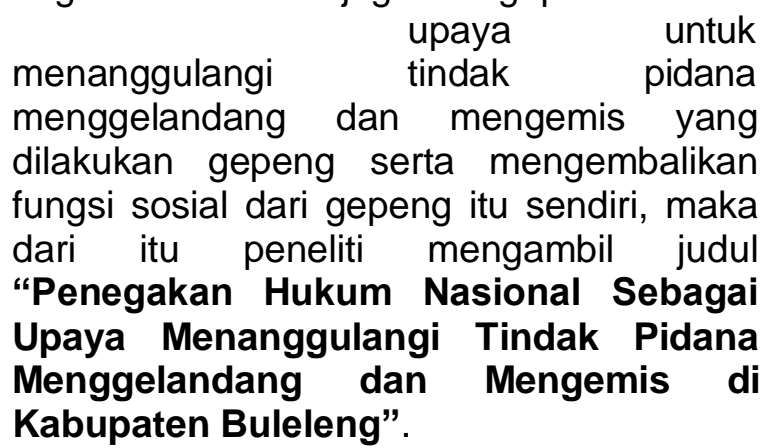

\section{METODE PENELITIAN}

Jenis penelitian yang digunakan dalam penelitian ini adalah penelitian hokum yuridis empiris (Ali, 2016:10). Penelitian hukum empiris ini merupakan penelitian yang bersifat deskriptif (Ali, 2012:2). Sumber data yang digunakan terdiri dari Data primer yang bersumber dari penelitian lapangan. Data skunder yang bersumber dari penelaahan studi kepustakaan berupa literatur, karya ilmiah (hasil penelitian), peraturan perundang- undangan, dokumentasi dari berbagai instansi dan data yang sudah didokumenkan, antara lain : Bahan hukum primer yang terdiri dari peraturan perundang-undangan yaitu UUD NRI 1945, KUHP, PP RI No 31 Tahun 1980, dan Perda No. 6 Tahun 2009 Kabupaten Buleleng. Bahan hukum sekunder yang bersumber dari jurnal, doktrin, dan hasil penelitian. Metode pengumpulan data yang dipergunakan adalah wawancara, pengamatan (observasi) dan kuisioner (Waluyo, 2008:8.). Teknik yang digunakan dalam penelitian ini adalah nonprobability sampling berbentuk proposiv sampling (Waluyo, 2008:46).

\section{PEMBAHASAN}

1. Faktor Penghambat dan Pendukung Penegakan Hukum Terhadap Gepeng di Kabupaten Buleleng

Proses penegakan hukum tidak menutup kemungkinan apabila dalam pelaksaaannya akan ditemukan faktor penghambat dan juga faktor pendukung yang dapat membuat pelaksanaan penegakan hukum dalam kehidupan masyarakat berjalan lebih efektif dan optimal. Pelaksanaan penegakan hukum pidana terhadap Gepeng tidak akan terlepas dari faktor yang mempengaruhi penegakan hukum itu sendiri. Faktor inilah yang menjadi indikator keberhasilan maupun efektivitas suatu penegakan hukum.

Masalah pokok penegakan hukum sebenarnya terletak pada faktor-faktor yang mempengaruhinya. Menurut Lawrence Meir Friedman dalam teorinya tentang penegakan hukum yang mana telah disesuaikan dengan kondisi yang ada di Indonesia, faktor yang mempengaruhi penegakan hukum tersebut meliputi (Soekanto, 2011:18) :

1. Faktor Substansi Hukum yang menunjuk pada faktor hukum atau peraturan itu sendiri.

2. Faktor Struktur Hukum yang menunjuk pada faktor penegak hukum dan fakor sarana/fasilitas.

3. Faktor Budaya Hukum yang menunjuk pada masyarakat dan kebudayaan.

\section{A. Faktor Penghambat Penegakan Hukum Terhadap Gepeng di Kabupaten Buleleng}

Berdasarkan teori yang dikemukakan oleh Lawrence Meir Friedman bahwasannya mengenai faktor penghambat penegakan hukum terhadap Gepeng di Kabupaten Buleleng meliputi :

\section{Substansi Hukum}

Faktor substansi hukum ini meliputi tentang hukum atau peraturan itu sendiri. Hukum positif Indonesia menegaskan bahwa kegiatan menggelandang dan mengemis di tempat umum dikualifikasikan sebagai suatu tindak pidana pelanggaran di bidang ketertiban umum sesuai ketentuan hukum yang berlaku. Berdasarkan hasil penelitian menunjukan hambatan terhadap penegakan hukum yang berasal dari faktor substansi hukum ini adalah dapat disebabkan karena:

a. Tidak diikutinya asas-asas berlakunya undang-undang.

b. Kurang jelasnya arti kata di dalam undang-undang yang mengakibatkan kesimpangsiuran di dalam penafsiran serta penerapannya. 
c. Aturan yang ada masih belum menyentuh masyarakat pemberi Gepeng.

Secara substansi, dalam Pasal 4 ayat (2) Perda No. 6 tahun 2009 kata "Gepeng" sama sekali belum disebutkan secara jelas sebagai perbuatan yang dilarang, dalam implementasinya di lapangan hal ini menimbulkan penafsiran yang kurang jelas karenanya terhadap ketentuan Pasal 4 ayat (2) Perda No. 6 tahun 2009 tersebut perlu dilakukan revisi dengan menambahkan kata "Gepeng" untuk memperjelas bunyi pasalnya. Kelemahan-kelemahan lain yang terlihat dalam pasal 504, 505 dan pasal 4 ayat 2 Jo. Pasal 21 ayat 1 dan 2 adalah aturan tersebut belum sampai menyentuh masyarakat pemberi kepada Gepeng, hal itu dibutuhkan karena faktor adanya masyarakat pemberi inilah yang menjadi salah satu faktor utama penyebab masih banyaknya jumlah Gepeng di Kabupaten Buleleng sehingga diharapkan dengan adanya aturan pidana bagi masyarakat yang memberikan uang atau sesuatu kepada Gepeng jelas akan membuat lahan operasi dari Gepeng tersebut menjadi semakin sempit. Pemberian sanksi pidana berupa pidana kurungan sulit diterapkan, karena melihat kondisi Lembaga Permasyarakatan di Kabupaten Buleleng yang penuh atau tidak akan mencukupi sehingga dibutuhkan kebijakan untuk menanganinya yaitu meliputi, Penjatuhan sanksi kurungan bagi Gepeng ini sebaiknya lebih diterapkan kepada para Gepeng kambuhan, Perlu segera dilakukan teroboson hukum dengan melakukan pembaharuan hukum pidana.

\section{Struktur Hukum}

Faktor struktur hukum ini lebih menekankan pada aspek lembaga/aparat penegak hukum beserta kinerjanya dan juga sarana/fasilitas pendukung yang dalam lingkup ini adalah jelas yang terkait dengan pelaksanaan penegakan hukum pidana terhadap Gepeng di Kabupaten Buleleng. Hasil penelitian dilapangan menunjukkan bahwa selama ini aparat penegak hukum terkait yaitu aparat Polres Buleleng, Dinas Sosial dan Satpol PP Kabupaten Buleleng, ternyata belum menunjukkan kinerja maksimal dalam proses penegakan hukum nasional yang mengacu pada hukum pidana sebagai upaya menanggulangi permasalahan Gepeng di Kabupaten Buleleng. Hal ini menunjukan tugas dan fungsi sebagai aparat penegak hukum tersebut belum dilaksanakan dengan baik. Terbukti dari tidak adanya upaya penegakan hukum terhadap ketentuan Pasal 504, 505 KUHP secara umum oleh aparat Polres Buleleng dan perda no. 6 tahun 2009 oleh aparat Satpol PP.

\section{Tabel 2}

\section{Pelimpahan perkara tindak pidana menggelandang dan mengemis ke Pengadilan Negeri Buleleng}

Sumber Data : berdasarkan hasil penelitian.

Tabel diatas menunjukan

bahwasannya penegakan hukum terkait Gepeng memang tidak sampai ke proses pelimpahan perkara yang mana menunjukan bahwasannya sikap yang kurang tegas yang dimiliki oleh aparat penegak hukum. Upaya penegakan hukum

\begin{tabular}{|c|c|c|c|}
\hline $\begin{array}{l}N \\
0\end{array}$ & Tahun & $\begin{array}{l}\text { Perkara } \\
\text { Pelanggaran } \\
\text { Pasal 504, } 505 \\
\text { KUHP }\end{array}$ & $\begin{array}{l}\text { Perkara } \\
\text { Pelanggaran } \\
\text { Pasal } 4 \text { ayat } \\
\text { (2) Jo. Pasal } \\
21 \text { ayat } 1 \text { dan } \\
2\end{array}$ \\
\hline 1 & 2013 & 0 & 0 \\
\hline 2 & 2014 & 0 & 0 \\
\hline 3 & 2015 & 0 & 0 \\
\hline 4 & 2016 & 0 & 0 \\
\hline 5 & 2017 & 0 & 0 \\
\hline $\mathrm{Tc}$ & & 0 & 0 \\
\hline
\end{tabular}

pidana terhadap ketentuan Pasal 504 dan 505 serta pasal 4 ayat (2) Jo. Pasal 21 ayat 1 dan 2 Perda No. 6 tahun 2009, yang selama ini dilakukan oleh aparat Satpol PP Kabupaten Buleleng terbukti belum dilaksanakan secara tuntas dan maksimal karena upaya yang dilakukan dari aparat Satpol PP yang lebih merujuk pada upaya refresiv dengan alasan kemanusiaan. Faktor penghambat yang menyebabkan aparat Kepolisian Resort Buleleng dalam hal menegakkan hukum nasional kepada Gepeng meliputi :

a. Terbatasnya Sumber Daya Manusia di Polres Buleleng.

b. Luasnya ruang lingkup tugas penegakan hukum yang disertai dengan kompleksnya permasalahan hukum di Kabupaten Buleleng 
c. Alat bukti dan unsur dari pasal yang disangkakan yaitu Pasal 504 dan 505 KUHP.

d. Permasalahan Gepeng sudah ditangani oleh pihak Satpol PP Kabupaten Buleleng.

Faktor inilah yang membuat aparat Kepolisian Resor Buleleng belum maksimal menjangkau permasalahan Gepeng di Kabupaten Buleleng. Mengenai sarana/fasilitas penunjang penegakan hukum pidana terhadap Gepeng, bahwasannya masih terdapat kekurangan yang mana dapat menghambat penegakan hukum terhadap Gepeng di Kabupaten Buleleng. Faktor penghambat dimaksud adalah Pemerintah Kabupaten Buleleng tidak mempunyai panti rehabilitasi/panti sosial yang representatif bagi Gepeng dan di khawatirkan tentang kondisi Lembaga Pemasyarakatan (LP) yang penuh apabila nanti adanya putusan terhadap Gepeng yang terkena sanksi kurungan bila saat di proses pada sidang Tipiring. Hambatan diatas adalah permasalahan klasik yang sudah sejak lama berlangsung yang perlu dicarikan solusi/pemecahannya bersama oleh semua pihak baik pemerintah, aparat penegak hukum maupun masyarakat.

\section{Budaya Hukum}

Faktor budaya hukum ini sangat terkait dengan faktor masyarakat yaitu lingkungan dimana hukum tersebut berlaku atau diterapkan, Hasil yang ad dilapangan menunjukan sebagai berikut:

a. Masih banyaknya masyarakat pemberi kepada Gepeng, hal ini tentu membuat semakin subur dan menjamurnya Gepeng yang mendorong mereka untuk datang ke kabupaten Buleleng. Memberikan sesuatu kepada Gepeng ini sangatlah tidak mendidik dan membuat mental Gepeng menjadi semakin malas.

b. Masih banyaknya anggota masyarakatnya yang bersikap acuh tak acuh dan terkesan tidak peduli dengan kondisi di sekitar. Selain itu, masyarakat Kabupaten Buleleng cenderung kurang mempunyai inisiatif yang lebih untuk melaporkan ke aparat/petugas terkait terhadap keberadaan Gepeng di lingkungan sekitar mereka.

Faktor masih adanya masyarakat pemberi dan sikap mayarakat yang kurang peduli terhadap permasalahan Gepeng inilah yang selama ini juga berkontribusi ikut menghambat kinerja aparat Satpol PP dan aparat Kepolisian Resort Buleleng untuk menertibkan atau menanggulangi permasalahan Gepeng. Faktor penghambat lainnya dari faktor budaya hukum ini adalah masih sangat lunak dan kurang tegasnya sikap mental yang ditunjukkan oleh aparat penegak hukum terhadap Gepeng yang terbukti melakukan kegiatan menggelandang dan mengemis di tempat umum. Budaya hukum yang kurang baik ini tidak akan memberikan efek jera kepada Gepeng sehingga tujuan untuk memperbaiki sikap mental dan membuat para Gepeng jera untuk menggelandang dan mengemis lagi sulit tercapai.

\section{B. Faktor Pendukung Penegakan Hukum Terhadap Gepeng di Kabupaten Buleleng. \\ Mengenai faktor pendukung pelaksanaan penegakan hukum pidana dalam rangka menanggulangi Gepeng di Kabupaten Buleleng adalah sebagai berikut:}

\section{Substansi Hukum}

Sebagaimana yang telah diuraikan, selama ini KUHP maupun Perda Kabupaten Buleleng diatas dianggap bertentangan dengan ketentuan Pasal 34 UUDNRI 1945, namun menurut peneliti ketentuan Pasal 34 UUDNRI 1945 tersebut tidaklah dapat dijadikan dasar atau alasan hukum untuk meniadakan tindakan tegas negara dalam menanggulangi masalah Gepeng demi mewujudkan ketertiban umum, memberikan rasa aman dan tenteram bagi masyarakat luas. maka sangat beralasan apabila diperlukan upaya penanggulangan yang lebih serius terhadap permasalahan Gepeng ini mulai dari yang sifatnya preventif sampai dengan upaya-upaya yang sifatnya represif melalui penegakan hukum pidana yaitu dengan penegakan ketentuan Pasal 504, 505 KUHP dan Pasal 4 ayat (2) Jo. Pasal 21 ayat 1 dan 2 Perda No. 6 
tahun 2009 tersebut. Aturan dan sanksi pidana terhadap Gepeng sebagaimana diatur dalam KUHP maupun Perda Kabupaten Buleleng tersebut, tetap diperlukan untuk menjaga ketertiban umum di masyarakat, melihat keberadaan Gepeng di Kabupaten Buleleng ini dirasa semakin mengganggu. Maka aturan dan sanksi pidana tersebut juga memang tetap diperlukan dan layak untuk dipertahankan mengingat ketentuan tersebut dapat memberikan efek jera dan memperbaiki sikap mental Gepeng agar dikemudian hari tidak lagi melakukan kegiatan tersebut. Aturan pidana tersebut diharapkan dapat bekerja dengan baik dalam kehidupan masyarakat Kabupaten Buleleng dan tentu saja menjadi faktor pendukung dalam pelaksanaan penegakan hukum terhadap Gepeng di Kabupaten Buleleng.

\section{Struktur Hukum}

Berdasarkan hasil penelitian faktor struktur hukum ini selain merupakan faktor penghambat ternyata didalamnya juga terdapat hal yang sifatnya mendukung pelaksanaan penegakan hukum terhadap Gepeng di Kabupaten Buleleng. Bagian dari faktor struktur hukum yang merupakan faktor pendukung adalah berkaitan dengan sarana/fasilitas penunjang penegakan hukum nasional terhadap Gepeng. Sarana dan fasilitas penegakan hukum yang dimiliki aparat penegak hukum Satpol PP Kabupaten Buleleng cukup memadai. Sarana dan fasilitas berupa mobil patroli, Handy Talky (HT), senjata pengamanan yang cukup dan ditunjang dengan jumlah petugas/aparat Satpol PP Kabupaten Buleleng yang cukup pula dapat menjadi modal pendukung pelaksanaan penegakan hukum terhadap Gepeng di Kabupaten Buleleng. Dukungan sarana dan fasilitas ini sejalan atau berbanding lurus dengan hasil penertiban yang telah dilakukan selama ini yaitu banyaknya Gepeng yang terjaring razia selama 5 tahun terakhir adalah sejumlah 170 orang.

\section{Upaya Penanggulangan Gepeng di Kabupaten Buleleng.}

Gepeng merupakan salah satu fenomena sosial yang terjadi akibat kemisinan yang tinggi serta keputusasaan terhadap pemerintah untuk memberikan kehidupan yang layak. Untuk memberikan perlindungan kepada masyarakat dari gangguan tindak pidana atau kejahatan, maka diperlukan adanya upaya penanggulangan dari pemerintah beserta aparat penegak hukum yang terkait. Upaya penanggulangan tindak pidana kejahatan ataupun pelanggaran hukum di masyarakat, dapat ditempuh melalui dua cara yaitu: Melalui jalur penal (hukum pidana) dan Melalui jalur non-penal.

Upaya yang telah dilakukan untuk menanggulangi tindak pidana menggelandang dan mengemis ini meliputi

1. Upaya operasi/razia

Berdasarkan hasil penelitian dengan mengkaji dan menganalisis berdasarkan teori upaya penanggulangan tindak pidana, maka upaya ini termasuk dalam upaya menanggulangi tindak pidana melalui jalur penal (hukum pidana). Upaya operasi/razia ini merupakan suatu bentuk upaya nyata yang dilakukan oleh Tim yustisi, yang peliputi Dinas Sosial, aparat Satpol PP dan aparat Kepolisian Resort Buleleng. Kegiatan yang didasarkan atas permasalahan Gepeng ini dilakukan kurang lebih sebanyak 3 kali dalam setahun. Upaya ini kurun waktu 5 tahun terakhir (periode tahun 2013-2017) menunjukkan bahwa, aparat penegak hukum dalam hal ini sudah gencar melakukan kegiatan operasi/razia serangkaian penertiban yang dilaksanakan dengan cara mendatangi Gepeng di tempat umum. Upaya ini terbukti telah dilakukan guna mencoba menertibkan dan menanggulangi Gepeng yang beroperasi diwilayah Kabupaten Buleleng dengan melihat banyaknya Gepeng yang terjaring razia selama lima tahun terakhir tahun 20132017 adalah sejumlah 170 orang.

Berdasarkan hasil penelitian upaya ini selama kurun waktu 5 tahun (periode tahun 2013-2017) dirasa cukup optimal untuk menertibkan lokasi kegiatan menggelandang dan mengemis sebagai wujud awal upaya menanggulangi tindak pidana menggelandang dan mengemis di wilayah Kabupaten Buleleng, peneliti sependapat berdasarkan hasil penelitian yang didapat bahwasannya upaya ini efektif 
dilakukan untuk menertibkan Gepeng sebagai langkah awal menanggulangi tindak pidana yang dilakukan Gepeng, tetapi akan lebih maksimal apabila pelaksanaan kegiatan operasi/razia ini dilakukan dalam 1 bulan sekali.

2. Upaya penampungan sementara untuk dilakukan seleksi.

Berdasarkan hasil penelitian dengan mengkaji dan menganalisis berdasarkan teori upaya penanggulangan tindak pidana, maka upaya ini termasuk dalam upaya menanggulangi tindak pidana melalui jalur penal (hukum pidana). Upaya penampungan sementara ini dilakukan untuk proses pendataan dan proses seleksi. Pada tahap ini dilakukan pendekatan persuasif yang intensif kepada Gepeng oleh Satpol PP dan Dinas Sosial untuk nantinya dapat ditentukan mengenai tindakan selanjutnya. Dalam tahap ini petugas akan memberikan pengertian, pemahaman dan mengajak para Gepeng

untuk meninggalkan kegiatan menggelandang dan mengemis di tempat umum. Pendekatan persuasif ini tidak mudah, perlu kesabaran untuk memberikan pengertian dan pemahaman serta kesadaran agar mereka mau meninggalkan kegiatan menggelandang dan mengemis di tempat umum. Hasil seleksi ini selanjutnya ditangani dalam 3 pendekatan, yaitu pertama melalui Sidang tindak pidana ringan (Tipiring), kedua diserahkan kepada Dinas Sosial Kabupaten Buleleng untuk dibawa ke rumah penampungan untuk diberikan pembinaan, dan yang ketiga dipulangkan ke daerah asal/kampung halaman.

Hasil penelitian yang ada kurun waktu 5 tahun terakhir ini (periode tahun 20132017) pihak Satpol PP Kabupaten Buleleng lebih memilih untuk menggunakan pendekatan yang kedua dan ketiga yaitu diserahkan kepada Dinas Sosial Kabupaten Buleleng untuk diberikan pembinaan yag sifatnya hanya berupa arahan dan dilakukan pemulangan ke daerah asal yang menjadi tugas dari Dinas Sosial Kabupaten Buleleng. Pendekatan yang dilakukan ini menimbulkan kembalinya masyarakat melakukan tindak pidana menggelandang dan mengemis khusunya dilakukan di daerah Kabupaten Buleleng.

\section{Rumah tinggal kreatif}

Berdasarkan hasil penelitian dengan mengkaji dan menganalisis berdasarkan teori upaya penanggulangan tindak pidana, maka upaya ini termasuk dalam upaya menanggulangi tindak pidana melalui jalur non-penal (diluar hukum pidana). Upaya ini merupakan bentuk program rehabilitasi yang akan dilakukan oleh Dinas Sosial Kabupaten Buleleng. Program Rumah Tinggal Kreatif ini berfungsi untuk tempat rehabilitasi mental dan pembinaan keterampilan yang diharapkan bisa menjadi salah satu alternative tempat untuk menanggulangipara Gepeng. Rumah tinggal kreatif ini dibangun dengan pembentukan sebuah manajemen pemberdayaan terhadap Gepeng dengan harapan setelah keluar dari rumah tinggal kreatif maka telah terjadi perubahan pola pikir dan jalan hidup bagi para Gepeng untuk memiliki hidup dan pekerjaan yang lebih baik dibandingkan melakukan kegiatan menggelandang dan mengemis di wilayah Kabupaten Buleleng.

Rumah tinggal kreatif ini akan ditangani oleh tenaga ahli di bidangnya, sebagai rehabilitasi mental maka dari itu akan diperlukan tenaga pendidik dan psikolog yang akan memberikan pengertian dan merubah pola pikir (mindset) dari para Gepeng untuk bisa meninggalkan kegiatanmenggelandang dan mengemis dengan pekerjaan yang lebih layak dan lebih baik. Setelah rehabilitasi mental tersebut dilakukan dengan baik maka akan diberikan pembinaan keterampilan yang bisa dipakai dan difungsikan untuk mata pencaharian dan pekerjaan bagi para Gepeng tersebut,yang Pada akhirnya tujuan untuk mengurangi jumlah Gepeng ini diharapkan bisa berfungsi dengan baik. Rumah tinggal kreatif ini masih menjadi wacana dari Dinas Sosial Kabupaten Buleleng dikarenakan dalam melaksanakan upaya ini akan sangat membebani APBD daerah Kabupaten Buleleng.

\section{PENUTUP}

\section{SIMPULAN}

1. Faktor penghambat penegakan hukum nasional terhadap Gepeng di Kabupaten Buleleng adalah faktor 
substansi hukum yaitu Gepeng belum secara tegas disebutkan dalam Perda No. 6 tahun 2009, dan belum adanya aturan pidana bagi masyarakat pemberi kepada Gepeng, faktor struktur hukum yaitu kinerja aparat penegak hukum yang belum maksimal, serta faktor budaya hukum yaitu masih kurang pedulinya masyarakat terhadap permasalahan Gepeng dan masih adanya masyarakat pemberi kepada Gepeng, serta sikap mental dari aparat penegak hukum yang kurang tegas terhadap Gepeng. Sedangkan faktor pendukung penegakan hukum nasional terhadap Gepeng adalah faktor substansi hukum yaitu KUHP maupun Perda No. 6 tahun 2009 masih diperlukan dan dipertahankan sebagai dasar pelaksanaan penegakan hukum di Kabupaten Buleleng, dan faktor struktur hukum berupa sarana/fasilitas yang memadai dari aparat penegak hukum dalam melaksanakan operasi/razia penertiban.

2. Upaya-upaya yang telah dilakukan untuk menanggulangi Gepeng di Kabupaten Buleleng yaitu upaya jalur penal dan non-penal. Upaya penal meliputi upaya operasi/razia guna menertibkan Gepeng yang beroperasi diwilayah Kabupaten Buleleng dan upaya penampungan sementara untuk di sleksi bertujuan untuk membedakan jenis pembinaan terhadap Gepeng yang terjaring operasi/razia. Sedangkan upaya non-penal meliputi program Rumah Tinggal Kreatif yang bertujuan untuk tempat rehabilitasi mental dan pembinaan keterampilan dengan harapan dapat merubah pola pikir dan jalan hidup para Gepeng untuk mendapatkan pekerjaan yang jauh lebih baik lagi.

\section{SARAN}

1. Perlu dilakukannya peningkatan kinerja dari Pemerintah maupun aparat penegak hukum, dalam melakukan koordinasi dan sinergi dari lembaga/aparat penegak hukum yang terkait yaitu dari Satpol PP Kabupaten Buleleng, Dinas Sosial Kabupaten Buleleng, Polres Buleleng dan
Pengadilan Negeri Buleleng supaya dalam pelaksanaan penegakan hukum terhadap Gepeng di Kabupaten Buleleng dapat dilakukan secara lebih tegas dan konsekuen agar mendapatkan hasil yang diharapkan.

2. Perlu dilakukannya evaluasi dan perbaikan secara menyeluruh yang harus segera dilakukan oleh Pemerintah Kabupaten Buleleng dan aparat penegak hukum terkait.Untuk mengatasi hambatan dalam penegakan hukum terhadap Gepeng, baik itu yang terkait dengan faktor struktur hukum (legal structure), faktor substansi hukum (legal substance) maupun faktor budaya hukum (legalculture).

\section{DAFTAR PUSTAKA}

\section{BUKU :}

Ali, H.Z. 2016, Metode Penelitian Hukum, Jakarta :Sinar Grafika Offset.

Arief, B.N. 2010, Masalah Penegakan Hukum Dan Kebijakan Hukum Pidana Dalam Penanggulangan Kejahatan. Jakarta : Kharisma Putra Utama.

Arief, B.N. 2008, Bunga Rampai Kebijakan Hukum Pidana. Jakarta : Prenada Media Group.

Bakhari Syaifull, 2014. Sistem Peradilan Pidana Indonesia. Yogyakarta : Pustaka Pelajar.

Masriani, Y.T. 2008. Pengantar Hukum Indonesia . Jakarta : Sinar Grafika.

Najih Mokhammad, 2014. Pengantar Hukum Indonesia. Malang : Setara Press.

Salman Otje, dan Susanto, A.F. 2008, Beberapa Aspek Sosiologi Hukum. Ed. Ke-2 Cet ke-1, Alumni, Bandung.

Sunggono Bambang, 2006, Metodologi Penelitian Hukum, Ed. 1 Cet. ke-8, Jakarta : PT. Raja Grafindo Persada.

Soekanto Soerjono, 2011. Faktor-faktor yang Mempengaruhi Penegakan Hukum. Jakarta : CV. Rajawali.

Waluyo Bambang, 2008 Penelitian Hukum Dalam Praktek. Jakarta : Sinar Grafika.

Yusrizal, 2012. Kapita Slekta Hukum Pidana \& Kriminologi. Jakarta : PT. SOFMEDIA.

\section{ARTIKEL :}


Anggari, K.D.A. dalam artikel Efektifitas Penanggulangan Gelandangan dan Pengemis Di Kabupaten Badung. diakses pada tanggal 13 September 2017.

Sedana Gede, dalam artikel Faktor Penyebab terjadinya Gelandangan dan Pengemis Kasus di Bali. diakses Tanggal 12 September 2017

\section{UNDANG-UNDANG :}

Munthe, C.A. 2014 KUHP \& KUHAP CERTE POSSE

Peraturan Pemerintah RI No. 31 Tahun 1980 tentang Penanggulangan Gelandangan dan Pengemis.

Peraturan Daerah Kabupaten Buleleng No. 6 Tahun 2009 tentang Ketertiban Umum. 